\title{
ANTISIPASI SISWA LEVEL ANALISIS DALAM MENYELESAIKAN MASALAH GEOMETRI
}

\author{
Sunardi ${ }^{\mathrm{a}}$, Erfan Yudianto ${ }^{\mathrm{b}}$ \\ Program Studi Pendidikan Matematika FKIP Universitas Jember \\ Jalan Kalimantan 37 Kampus Tegalboto Jember \\ asunardi.fkip@unej.ac.id, berfanyudi@unej.ac.id
}

\begin{abstract}
ABSTRAK
Penelitian ini dilatarbelakangi oleh kesulitan siswa menyelesaikan masalah geometri khususnya pada pokok bahasan dimensi tiga (kubus). Sebenarnya beberapa konsep ada pada kepala siswa dan siswa sudah tepat dalam menentukan prosedur terkait masalah yang diberikan, tetapi pada tahap akhir siswa tidak tepat dalam menentukan jawaban. Tujuan penelitian ini untuk mendeskripsikan antisipasi siswa pada level analisis dalam menyelesaikan masalah geometri. Dalam penelitian ini data dikumpulkan dengan metode tes dan wawancara. Tes berupa pengklasifikasian level van Hiele yang diberikan kepada siswa yang diadopsi dari (Sunardi, 2000), sehingga diperoleh siswa pada level analisis. Wawancara dilakukan kepada siswa pada level tersebut. Hasil penelitian ini adalah siswa pada level analisis berturut-turut termasuk pada antisipasi analitik, antisipasi kaku, dan antisipasi terinternalisasi. Hasil penelitian diharapkan dapat dimanfaatkan oleh siswa dan guru, sehingga informasi ini mampu diterapkan dalam pembelajaran di kelas.
\end{abstract}

Kata Kunci: Antisipasi, level analisis, geometri dimensi tiga

\begin{abstract}
This research is motivated by the difficulty students solve problems of geometry in particular on the subject of three-dimensional (cube). Actually there are a few concepts at the head of the student and the student has the right to determine the procedures related to the given problem, but at the final stage students are not appropriate in determining the answer. This study, data were collected by the method of tests and interviews. Tests such as van Hiele level classification given to a student who was adopted from Sunardi (2000), in order to obtain the students at the level of analysis. Interviews were conducted to students at that level. Results of this study were students at successive levels of analysis including the analytic anticipation, tenacious anticipation, and interiorized anticipation. Results are expected to be used by students and teachers, so that this information is able to be applied in the classroom.
\end{abstract}

Keyword: Anticipation, analysis level, van Hiele Level, three-dimensional geometry

\section{Pendahuluan}

Geometri merupakan salah satu

topik dalam pembelajaran matematika yang dirasa sulit bagi sebagian besar siswa. Hal tersebut terlihat dari hasil ulangan harian siswa kelas X SMA Darus
Sholah Jember (merupakan sekolah unggulan BPPT) tahun pelajaran 2014/2015 pada pokok bahasan dimensi tiga. Dari 82 siswa terdapat 61 siswa atau $74,39 \%$ mendapatkan nilai < 60 , sedangkan sisanya 21 siswa atau $25,61 \%$ 
mendapatkan nilai $\geq 60$. Menurut Clements dan Battista (dalam Putra, dkk. 2005:1) beberapa peneliti melaporkan bahwa pembelajaran geometri masih jauh dari harapan yang ditandai oleh rendahnya pemahaman siswa. Hasil penelitian Sunardi, dkk. (1998:23) pada siswa kelas 2b SLTPN 4 Jember menyatakan bahwa $83,3 \%$ siswa melakukan kesalahan dalam menyelesaikan soal tentang sudut luar berseberangan, $52,37 \%$ tentang sudut berpelurus, $40,5 \%$ tentang sudut luar sepihak, 36,95\% tentang sudut dalam sepihak, dan $33,62 \%$ tentang sudut dalam berseberangan. Lebih lanjut, Sunardi (2001) mengungkapkan bahwa banyak siswa salah dalam menyelesaikan soalsoal mengenai garis sejajar pada siswa SMP dan masih banyak siswa yang menyatakan bahwa belah ketupat bukan jajargenjang. Usiskin (1987:17), melaporkan data dari National Assesment tahun 1982, bahwa kurang dari 10\% siswa berumur 13 tahun tidak dapat menentukan sebuah sudut segitiga jika sudut yang lainnya diketahui. Hanya 20\% siswa yang dapat menentukan panjang hipotenusa segitiga siku-siku yang diketahui kakikakinya.

Tokoh yang berkaitan langsung dengan pembelajaran Geometri adalah Pierre Marie van Hiele dan Dina van Hiele-Geldof. Sekitar tahun 1950-an secara internasional telah diakui teori yang dikembangkan oleh pasangan suami istri dari Belanda itu. Uni Soviet dan
Amerika serikat adalah dua negara yang telah mengubah kurikulum geometri berdasarkan teori van Hiele. Sepuluh tahun kemudian, sekitar tahun 1960-an, Uni Soviet telah melakukan perubahan kurikulum karena pengaruh teori van Hiele, sedangkan di Amerika Serikat baru sekitar tahun 1070-an pengaruh teori van Hiele mulai terasa. Menurut teori van Hiele, seseorang akan melalui lima level hierarkis pemahaman dalam belajar geometri (van Hiele, 1999:311; van de Walle, 1994:325-326; D'Augustine dan Smith, 1992:276; Clements dan Battista, 1992:426-428; Fuys, dkk. 1988:5; Crowley, 1987:2-3; Burger \& Shaughnessy, 1986b:1). Lima level tersebut adalah: level 0 (visualisasi), level 1 (analisis), level 2 (deduksi informal), level 3 (deduksi), dan level 4 (rigor). Setiap level menunjukkan proses berpikir yang digunakan seseorang dalam belajar konsep geometri. Level-level itu menunjukkan bagaimana seseorang berpikir dan tipe ide-ide geometri apa yang dipikirkan; jadi bukan me-nunjukkan seberapa banyak pengetahuan yang dimiliki siswa.

Level 0 (Visualisasi): Level ini sering disebut level pengenalan. Pada level ini siswa sudah mengenal bangunbangun geometri, misalnya persegi, persegipanjang, segitiga, jajargenjang. Namun bentuk-bentuk geometri yang dikenal anak semata-mata didasarkan pada karakteristik visual atau penampakan 
bentuknya secara keseluruhan, bukan perbagian. Dalam mengidentifikasi bangun, mereka seringkali menggunakan prototipe visual. Sebagai contoh, mereka mengatakan bahwa bangun yang diketahui adalah persegipanjang, karena seperti daun pintu. Anak belum menyadari adanya sifat-sifat dari bangun geometri.

Level 1 (Analisis): Level ini juga disebut level deskripsi. Pada level ini anak-anak sudah mengenal sifat-sifat bangun geometri yang didasarkan pada analisis informal tentang bagian-bagian bangun dan atribut-atribut komponennya. Pada level ini mulai banyak adanya analisis terhadap konsep-konsep geometri. Anak-anak dapat mengenali dan menentukan karakteristik bangun berdasarkan sifat-sifatnya. Melalui pengamatan, eksperimen, mengukur, menggambar, dan membuat model, siswa dapat mengenali dan membedakan karakteristik suatu bangun. Anak-anak melihat bahwa suatu bangun mempunyai bagian-bagian tertentu yang dapat dikenali. Namun demikian anak-anak belum sepenuhnya dapat menjelaskan hubungan antara sifat yang satu dengan sifat yang lain, anak-anak sama sekali belum bisa melihat hubungan antara beberapa bangun, dan definisi abstrak belum atau tidak dapat dimengerti. Suatu contoh, anak belum bisa menyatakan bahwa persegipanjang juga merupakan jajargenjang.
Level 2 (Deduksi Informal): Level ini sering disebut level abstraksi atau tingkat pengurutan. Pada level ini anakanak dapat melihat hubungan antar sifatsifat dalam satu bangun. Misal, dalam belahketupat, sisi yang berhadapan sejajar mengharuskan sudut-sudut yang berhadapan sama besar. Siswa juga dapat melihat hubungan sifat diantara beberapa bangun. Suatu contoh, belahketupat adalah jajargenjang karena sifat-sifat jajargenjang juga dimiliki oleh belahketupat. Siswa dapat mengurutkan secara logis sifat-sifat bangun. Misalnya, siswa menyatakan bahwa persegi juga merupakan belah ketupat dan belah ketupat juga merupakan jajargenjang. Siswa dapat menyusun definisi dan menemukan sifat-sifat bangun melalui induktif atau deduksi informal. Definisi yang dibangun tidak hanya berbentuk deskripsi tetapi merupakan hasil dari pengaturan secara logis dari sifat-sifat konsep yang didefinisikan.

Level 3 (Deduksi): Pada level ini berpikir deduksi siswa sudah mulai berkembang dan penalaran deduksi sebagai cara untuk membangun struktur geometri dalam sistem aksiomatik telah dipahami. Hal ini telah ditunjukkan siswa dengan membuktikan suatu pernyataan tentang geometri dengan menggunakan alasan yang logis dan deduktif. Suatu contoh, siswa telah mampu menyusun bukti jika sisi-sisi berhadapan suatu segiempat saling sejajar maka sudut-sudut 
yang berhadapan sama besar. Struktur deduktif aksiomatik yang lengkap dengan pengertian pangkal, postulat/aksioma, definisi, teorema, dan akibat yang secara implisit ada pada tingkat deduksi informal, menjadi objek yang eksplisit dalam pemikiran anak pada tingkat ini. Siswa telah mampu mengembangkan bukti lebih dari satu cara. Timbal balik antara syarat perlu dan syarat cukup dipahami. Perbedaan antara pernyataan dan konversnya dapat dimengerti siswa.

Level 4 (Rigor atau Akurasi): Pada level ini siswa dapat bekerja dalam berbagai struktur deduksi aksiomatik. Siswa dapat menemukan perbedaan antara dua struktur. Siswa memahami perbedaan antara geometri Euclides dan geometri non-Euclides. Siswa memahami aksiomaaksioma yang mendasari terbentuknya geometri non-Euclides.

Dari beberapa hasil penelitian terkait dengan level berpikir siswa menurut teori di atas, menyatakan bahwa sebagian besar siswa di sekolah masih berada di tiga level pertama. Hal ini ditengarai bahwa siswa belum mampu mengaitkan antar konsep geometri yang ada dalam pikirannya. Hal ini berarti jaringan konsep yang dimiliki siswa SMA sudah terbentuk, tetapi siswa masih belum dapat mengaitkan konsep-konsep yang saling terkait. Cobb (1985), melaporkan hasil penelitiannya bahwa jaringan konsep merupakan level tertinggi dari antisipasi.
Menurut Kamus Besar Bahasa Indonesia, antisipasi adalah perhitungan tentang hal-hal yang akan (belum) terjadi; bayangan; ramalan, atau penyesuaian mental terhadap peristiwa yang akan terjadi. Antisipasi merupakan sebuah konsep yang muncul dalam kesadaran sebelum adanya persepsi terhadap hal-hal yang dihadapi seseorang. Persepsi muncul sebagai suatu prinsip kognisi secara formal dan apriori dari suatu pengalaman. Jadi seseorang memiliki antisipasi sebelum persepsi dan terjadi sebelum mengalami. Secara filosofis, antisipasi digunakan dalam previsi (melihat lebih dulu) pengalaman yang mungkin, perkiraan tentang hasil-hasil studi yang telah dilakukan. Secara psikologis, antisipasi merupakan sikap terhadap situasi tertentu dan ide-ide tentang hasilhasil tindakan sebelum tindakan dilakukan. Secara logika, antisipasi dimaknai sebagai penerimaan sementara suatu premis yang dibuktikan dalam kaitannya dengan substansi selanjutnya yang dibuktikan. Pengertian di atas menunjukkan bahwa dalam menghadapi suatu masalah seseorang perlu membuat langkah-langkah atau gambaran tentang kemungkinan-kemungkinan yang akan terjadi. Implikasi terhadap pembelajaran geometri yaitu dalam menghadapi masalah matematika di sekolah, siswa perlu mengantisipasi terhadap setiap masalah yang dihadapi sehingga akan menghasilkan penyelesaian yang tepat. 
Cifarelli (1998) melanjutkan penelitian Cobb dengan memfokuskan pada hubungan antara atisipasi dengan jaringan konsep. Dia menemukan bahwa siswa mengalami perkembangan dalam menyelesaikan masalah matematika, begitu juga dengan jaringan konsep yang dimiliki siswa dalam menyelesaikan suatu masalah matematika. Ini berarti semakin kompleks jaringan konsep yang dimiliki siswa maka semakin besar antisipasi yang dilakukan siswa. Sejalan dengan itu, Lim (2006:105) mengatakan bahwa antisipasi dalam menyikapi masalah sangat diperlukan dalam menyelesaikan masalah.

Lebih lanjut Yudianto (2013: 28) mengatakan bahwa pengetahuan awal siswa dapat berupa pengetahuan yang sudah cocok dengan pengetahuan yang akan dipelajari (konsepsi awal atau prakonsepsi) atau berbeda sama sekali (misconcepsi). Jika yang terjadi misconcepsi maka siswa akan mengalami konflik kognitif. Harel (2006) mengatakan bahwa konflik kognitif dapat membantu siswa meningkatkan cara berpikir dan cara memahami suatu masalah. Berdasarkan penjelasan di atas, dapat disimpulkan bahwa antisipasi merupakan tindakan seseorang dalam mempertimbangkan setiap tindakan mental yang ada dalam kerangka berpikirnya yang dipengaruhi oleh struktur jaringan kecerdasan yang terkait di masa lalu.
Yudianto (2011) melakukan penelitian kepada 458 siswa dari 12 Sekolah Dasar di Jember Kota. Hasil penelitian menunjukkan bahwa persentase responden pada level visualisasi, analisis, deduksi informal, deduksi, dan rigor berturut-turut adalah 70,09\%; 28,38\%; $1,75 \%$; $0 \%$; dan $0 \%$; sedangkan $8,73 \%$ siswa diklasifikasikan pada tingkat transisi dan $16,16 \%$ siswa sulit diklasifikasikan dalam suatu tingkat perkembangan. Hasil penelitian di atas menunjukkan bahwa sebagian besar siswa sekolah dasar masih belum mencapai tahap visualisasi. Penelitian yang dilakukan Sunardi (2000) kepada 576 siswa dari 13 kelas pada 13 SLTPN di Jember menunjukkan bahwa persentase responden pada tingkat visualisasi, analisis, deduksi informal, deduksi, dan akurasi berturut-turut adalah $44,62 \% ; 34,55 \% ; 6,77 \%$; $0,17 \%$; dan $0 \%$. Responden yang tidak dapat diklasifikasikan pada suatu tingkat sebanyak 14,40\%. Selanjutnya, Sunardi (2002) meneliti tentang hubungan antara tingkat penalaran formal dan tingkat perkembangan konsep geometri yang diberikan kepada 387 siswa dari kelas sains tahun ketiga pada 10 SMA Negeri di Jember menunjukkan bahwa persentase responden pada tingkat visualisasi, transisi, deduksi informal, dan formal berturut-turut adalah $8,01 \% ; 24,81 \%$; 29,97\%; dan $37,21 \%$, sedangkan persentase responden pada tingkat pravisualisasi, visualisasi, analisis, 
deduksi informal, deduksi, dan rigor berturut-turut adalah 14,47\%; 31,52\%; $40,05 \% ; 13,44 \% ; 0,52 \%$; dan $0 \%$. Ada hubungan yang signifikan antara tingkat kemampuan berpikir logis dengan tingkat pemahaman dalam geometri.

Masalah antisipasi diungkap oleh Lim (2006) yang difokuskan pada karakteristik berpikir siswa terhadap materi aljabar. Berdasarkan hasil penelitiannya, Lim mengklasifikasikan subjek ke dalam lima antisipasi yaitu: (1) antisipasi impulsif yaitu siswa secara spontan melanjutkan dengan suatu tindakan yang datang pada pikirannya tanpa menganalisa masalah dan tanpa mempertimbangkan relevansi antisipasi ke suatu masalah, (2) antisipasi kaku yaitu siswa mempertahankan dan tidak mengevaluasi kembali pemahamannya terhadap masalah, sehingga merasa tidak perlu (mengabaikan) informasi baru yang datang dalam pikirannya, (3) antisipasi eksploratif yaitu siswa menggali ide untuk mendapatkan pemahaman yang lebih baik dari suatu masalah, (4) antisipasi analitik yaitu siswa menganalisis masalah dan menetapkan tujuan atau kriteria yang telah direncanakan kemudian menerapkan prosedur tertentu berdasarkan logika, analisis matematis, dan analisis logis, dan (5) antisipasi terinternalisasi yaitu siswa secara spontan menerapkan dan menetapkan kriteria suatu masalah, karena siswa telah mempertimbangkan dugaan yang relevan dari tindakan antisipasi ke situasi yang dihadapinya. Antisipasi ini penting diketahui oleh guru karena dapat membantu siswa dalam memahami masalah lebih baik.

Berdasarkan pemaparan di atas, dapat disimpulkan bahwa sebagian besar hasil penelitian masih pada tiga tingkat awal teori van Hiele. Untuk mengantisipasi pokok bahasan dimensi tiga, siswa harus memahami masalah yang diberikan. Setidaknya siswa mampu mengetahui hubungan antar bangun geometri yang diberikan. Hal ini didasarkan pada hasil penelitian sebelumnya yang menyatakan bahwa masih banyak siswa yang belum mencapai tingkat analisis, maka perlu dilakukan penelitian tentang masalah antisipasi siswa pada tingkat analisis dalam menyelesaikan masalah geometri.

Berdasarkan latar belakang yang telah diuraikan, maka pertanyaan penelitian yang diajukan adalah "bagaimana antisipasi siswa pada tingkat analisis dalam menyelesaikan masalah geometri?"

\section{Metode Penelitian}

Tujuan penelitian ini adalah memperoleh informasi mengenai antisipasi siswa pada tingkat analisis dalam menyelesaikan masalah geometri. Dalam melakukan pemeriksaan itu, peneliti bertindak sebagai instrumen utama artinya keberadaan peneliti tidak dapat digantikan oleh orang lain ataupun 
sesuatu yang lain. Dalam penelitian ini juga tidak dilakukan manipulasi terhadap suatu variabel, namun lebih diutamakan hal-hal yang dilakukan siswa pada saat kegiatan pengambilan data. Dengan demikian, penelitian ini menggunakan pendekatan kualitatif (Moleong, 2011). Jika dilihat dari tujuan penelitian, maka penelitian ini merupakan penelitian deskriptif sedangkan jika dilihat dari tujuan spesifiknya yaitu mengeksplorasi apa yang dipikirkan dan dilakukan oleh siswa, maka penelitian ini tergolong penelitian eksploratif. Dengan demikian jenis penelitian ini adalah deskriptifeksploratif.

Subjek dalam penelitian ini adalah 3 siswa yaitu siswa SMA kelas XI dan kelas XII dengan kriteria siswa berada pada tingkat analisis berdasarkan teori van Hiele. Subjek pertama $\left(\mathrm{S}_{1}\right)$ adalah $\mathrm{U}$ siswa kelas XI, subjek kedua $\left(\mathrm{S}_{2}\right)$ adalah $\mathrm{N}$ siswa kelas XI dan subjek ketiga $\left(S_{3}\right)$ adalah J siswa kelas XII.

\section{Hasil dan Pembahasan}

Permasalahan yang diberikan kepada subjek yaitu: "diketahui kubus $A B C D . E F G H$ dengan panjang rusuk $D H=8 \mathrm{~cm}$. Tentukan jarak dari titik $C$ ke garis $B H$ !". $\quad \mathrm{S}_{1}$ membaca soal sebanyak 4 kali kemudian dia mulai mensketsa kubus yang dimaksudkan soal. Perhatikan Gambar 1 yang dibuat oleh $S_{1}$. Dia tidak terlalu jelas mensketsa kubus. Pada gambar 1.a, $\mathrm{S}_{1}$ mensketsa kubus dengan membutuhkan waktu cukup lama, kemudian dia menggantinya dengan gambar 1.b, tidak lama lagi $S_{1}$ mengganti kembali menjadi gambar 1.c. Dalam hal ini $S_{1}$ memahami masalah dengan cara mengulang-ulang mensketsa kubus.

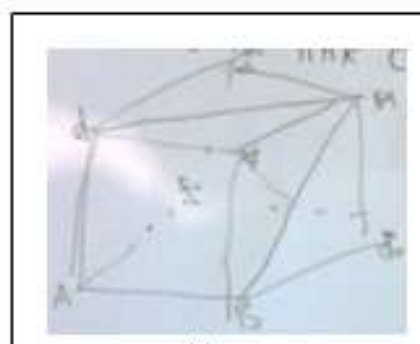

(a)

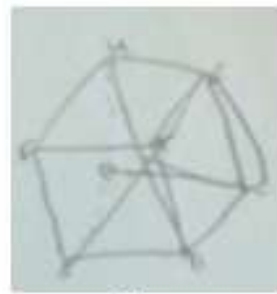

(b)

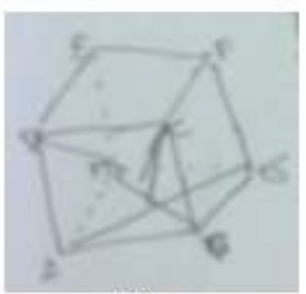

(c)

Gambar 1. Sketsa kubus berdasarkan pemahaman $S_{1}$

Pemahaman $S_{1}$ ini dapat dilihat dari transkrip wawancara berikut.

$$
\begin{aligned}
\mathrm{P}: & \text { Bagaimana menurut } \\
& \text { pandapatmu tentang masalah } \\
& \text { ini? (sambil menunjuk soal) } \\
\mathrm{S}_{1}: & \text { Ini gampang pak, tingggal } \\
& \text { menggambar kubusnya . . . }
\end{aligned}
$$

(lalu bergumam sambil membaca soal kembali). . . jelek gambarnya pak. Hehehehe

P : Tidak masalah ....

$S_{1}$ : Eh ... salah pak .... Ini yang benar .... (menunjuk gambar 1.b kemudian membaca soal 


\section{lagi dengan mengerutkan dahi) \\ ...... ini pak ini yang ini yang \\ benar (menunjuk gambar 1.c) \\ $\mathrm{P} \quad$ : Oke}

$\mathrm{S}_{1}$ membuat sketsa kubus sebanyak 3 kali, hal ini dikarenakan $S_{1}$ tidak yakin terhadap sketsa kubus sebelumnya. Setiap membaca soal maka $\mathrm{S}_{1}$ mengubah gambar kubusnya. Padahal berdasarkan pantauan peneliti, $S_{1}$ sudah tepat dalam menggambar kubus meskipun gambarnya tidak sesuai dengan harapan peneliti. Pada saat $S_{1}$ membaca soal kembali ternyata $S_{1}$ mengganti kembali sketsa kubusnya seperti terlihat pada gambar 2.

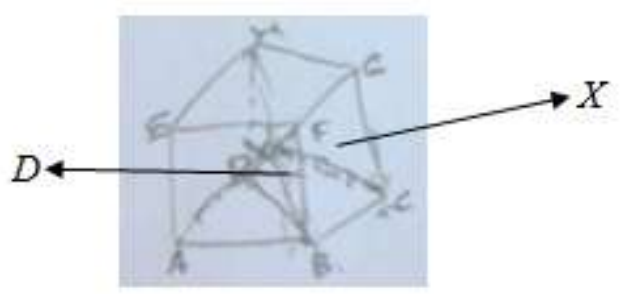

Gambar 2. Sketsa kubus keempat oleh $\mathrm{S}_{1}$

Pada gambar 2, memang berbeda dari sketsa-sketsa sebelumnya, pada gambar 2 ini kubus terlihat lengkap. Sekali lagi $S_{1}$ "menyempurnakan" sketsa kubus sebelum
$\mathrm{S}_{1}$ menerapkan perhitungan-perhitungan. Hal ini terlihat dari transkrip wawancara berikut.

$\mathrm{P} \quad$ : Ini gambar apa mas?

$S_{1}$ : Kubus terbaru pak, he he he (subjek tertawa kecil)

$\mathrm{P} \quad$ : Lo buat lagi ya?

$S_{1}$ : Iya pak .... Ini saya yakin, setelah dipikir-pikir ini yang tepat pak.

$\mathrm{P} \quad$ : Baiklah mas

Berdasarkan tes pengelompokan tingkat menurut van Hiele, $S_{1}$ masuk pada tingkat 1 yaitu analisis. $S_{1}$ sangat yakin dan memahami bahwa rusuk-rusuk pada kubus adalah sama yaitu $8 \mathrm{~cm}$. Hal ini berarti dia sudah mengenal sifat-sifat yang dimiliki kubus yang diamatinya. $\mathrm{S}_{1}$ mampu menyebutkan keteraturan yang ada pada kubus, dia kemudian mengerjakan dengan cara menentukan unsur-unsur yang dibutuhkan dalam menjawab masalah itu. Dengan menerapkan rumus teorema phitagoras, dia menentukan panjang $D B$ untuk mendapatkan panjang $B H$.

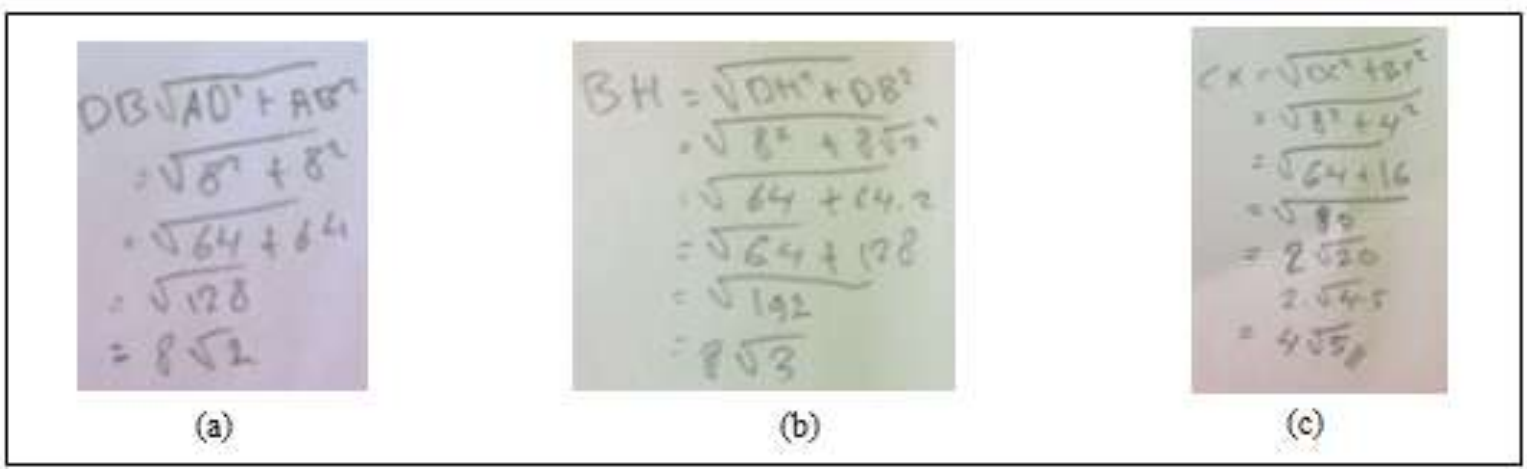


Gambar 3. Hasil Pekerjaan $S_{1}$

Dalam mencari panjang $D B \quad \mathrm{P} \quad$ : Ok

(diagonal bidang) dan panjang $B H$

(diagonal ruang) $S_{1}$ tidak mengalami

Berarti $\mathrm{S}_{1}$ dapat dikatakan kesulitan. Dalam menentukan jarak dari titik $C$ ke garis $B H$ dia kebingungan, tetapi dia terus mengulang-ulang dalam memahami soal yang diberikan. $\mathrm{S}_{1}$ kembali lagi ke bagian awal (membaca soal) kemudian memperhatikan kembali hasil pekerjaannya kemudian terdiam saat menentukan jarak dari titik $C$ ke garis $B H$. Poin penting dari kegiatan penelitian ini adalah $S_{1}$ tidak putus asa dalam memecahkan masalah. Dia berusaha terus mengaitkan hal-hal yang mungkin dari masalah yang diberikan. Hal ini terlihat dari coretan-coretan sebelum menentukan jarak dari titik $C$ ke garis $B H$. Konfirmasi dilakukan kepada $S_{1}$ melalui wawancara. Hal ini terlihat dari transkrip wawancara berikut.

$\mathrm{P}$ : Ada apa mas? (menanyakan kepada subjek karena subjek terlihat kebingungan)

$\mathrm{S}_{1}$ : Ini kan mencari jarak ya pak? .... berarti ini segitiga .....berarti ini .... Ini ....(subjek mengulang untuk membaca kembali soal yang diberikan dan juga mengamati hasil pekerjaan sebelumnya)

$\mathrm{P}$ : Terus?

$\mathrm{S}_{1}:$ Hemmm .... hemmm ... Bingung pak memiliki beberapa konsep dalam pikirannya dan dia berusaha untuk memanggil kembali (recall) konsep yang dimilikinya dan dalam penelitian ini disebut sebagai jaringan konsep. Selanjutnya Cobb (1985) mengatakan bahwa jaringan konsep merupakan level tertinggi dari antisipasi. Antisipasi subjek terhenti saat subjek akan menentukan jarak dari titik $C$ ke garis $B H$. Perhatikan gambar 2, $S_{1}$ menentukan panjang garis $C X$ (gambar 3.c), padahal letak titik sudut $D=X$ dan titik sudut $C$ ada dua (gambar 2).

Subjek kedua $\left(\mathrm{S}_{2}\right)$ mulai mensketsa kubus hanya satu kali dan membaca soal hanya satu kali juga. Perhatikan gambar 4.

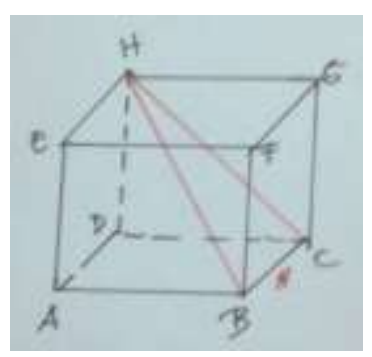

Gambar 5. Hasil Sketsa Kubus $S_{2}$

Hasil sketsa kubus yang dibuat $S_{2}$ sangat rapi, $\mathrm{S}_{2}$ menggunakan dua alat tulis berwarna merah dan hitam. Warna hitam digunakan untuk mensketsa rusuk-rusuk kubus sedangkan warna merah digunakan untuk membuat segmen garis $B H$ dan 
$\mathrm{CH}$. Hal ini terlihat dari kutipan wawancara berikut.

$\mathrm{P}$ : Untuk apa mbak dua pulpen itu?

$\mathrm{S}_{2}$ : Ini pak .... ini untuk buat kubusnya (menunjuk pulpen hitam) dan yang satunya untuk garis-garis di dalamnya.

$\mathrm{P}$ : Nah digunakan untuk apa mbak?

$\mathrm{S}_{2}$ : Biar keliatan mana yang akan saya kerjakan pak .. hehehe

Ini berarti siswa memahami masalah yang ditanyakan oleh soal. Berdasarkan hasil pengamatan $S_{2}$ tidak mengalami kesulitan dalam menyelesaikan masalah yang diberikan. $\mathbf{S}_{2}$ melanjutkan dengan mensketsa sebuah segitiga siku-siku, ini mengindikasikan $\mathrm{S}_{2}$ bukan pada tingkat Visualisasi. Perhatikan Gambar 6 berikut.

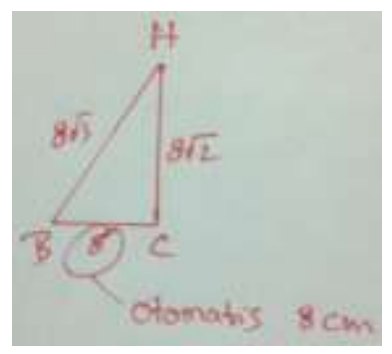

Gambar 6. Hasil Pekerjaan $S_{2}$

Dari Gambar 6, dapat disimpulkan bahwa $\mathrm{S}_{2}$ dapat diklasifikasikan pada jenis antisipasi kaku. Hal ini dikarenakan $\mathrm{S}_{2}$ secara spontan menentukan jarak dari titik $C$ ke $B H$ yaitu $8 \mathrm{~cm} . \mathrm{S}_{2}$ menganggap bahwa jarak terpendek dari sisi-sisi segitiga pada Gambar 6 di atas adalah 8 cm. Sebenarnya konsep jarak sudah terbentuk pada pikiran siswa, hal ini terlihat dari pemahaman siswa bahwa jarak itu adalah "garis terpendek" dari bangun geometri di atas. Perhatikan kutipan wawancara berikut.

$\mathrm{P}$ : Hasil akhirnya berapa mbak?

$\mathrm{S}_{2}: 8 \mathrm{~cm}$ pak

$\mathrm{P}$ : Sudah yakin hasilnya $8 \mathrm{~cm}$

$\mathrm{S}_{2}$ : Sudah pak ..... itu pak BC 8 $\mathrm{cm}, \mathrm{CH} 8 \sqrt{2} \mathrm{~cm}$ dan $\mathrm{BH} 8 \sqrt{3}$, itu kan berarti yang terpendek $8 \mathrm{~cm}$

P : Apakah mbak Nancy sudah yakin?

$S_{2}$ : Sudah pak .... yakin $200 \%$ hehehehe ...

Berdasarkan hasil wawancara di atas, $S_{2}$ sudah yakin dengan jawabannya. Dia menolak memeriksa kembali hasil pekerjaannya dengan mempertahankan pemahaman yang dimilikinya dengan indikasi pernyataan "yakin 200\%", hal itu terlihat dari transkrip wawancara.

Subjek ketiga $\left(S_{3}\right)$ memulai pekerjaannya dengan menketsa kubus ABCD.EFGH. Menjadi unik hasil sketsanya dikarenakan $\mathrm{S}_{3} \quad$ memulai menuliskan titik sudut-titik sudutnya dari belakang. Ini berarti $S_{3}$ mengetahui aturan-aturan yang berlaku dalam membuat kubus (tidak kaku). Perhatikan hasil pekerjaan $S_{3}$ pada gambar 7 berikut. 


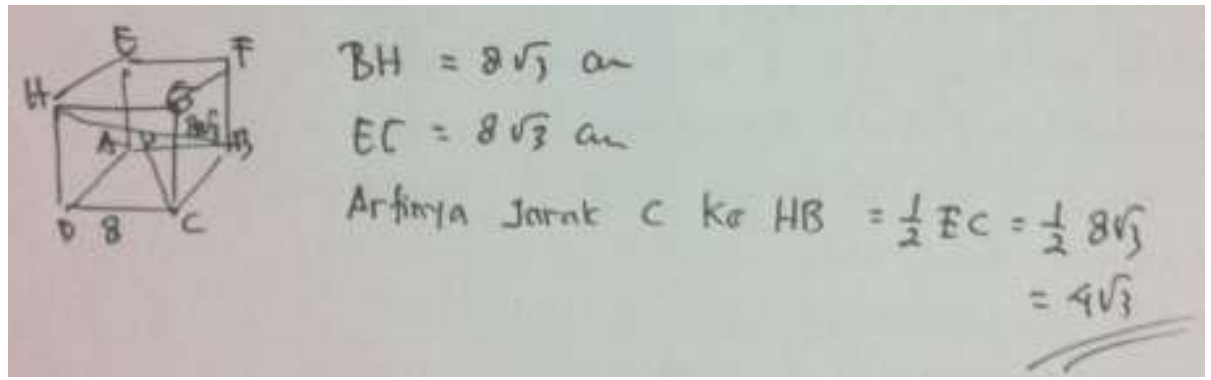

Gambar 7. Hasil Sketsa $\mathrm{S}_{3}$

Setelah membaca soal satu kali, $\mathrm{S}_{3}$ langsung mengerjakan soal yang diberikan. Dengan mensketsa, kemudian dengan cepat menentukan panjang $B H$ dan panjang $E C$ tanpa membuat coretan. Hal ini dikarenakan $S_{3}$ sudah familiar dengan soal seperti itu (kubus). Dia menjelaskan bahwa setiap rusuk pada kubus pasti sama panjang, diagonal sisinya selalu $\sqrt{2}$ dan diagonal ruangnya selalu $\sqrt{3}$. Berbeda dengan $S_{2}$, dimana $S_{2}$ menjelaskan dengan mensketsa segitiga siku-siku. Perhatikan transkrip wawancara berikut.

$\mathrm{P}$ : Mas, kenapa tiba-tiba menuliskan $\quad B H=8 \sqrt{3} \quad$ dan $E C=8 \sqrt{3}$

$\mathrm{S}_{3}$ : Nah itu kan diagonal ruang pak...

$\mathrm{P} \quad$ : Darimana nilai itu mas?

$\mathrm{S}_{3}$ : Ini kan pake segitiga lalu pake phitagoras dan dapat itu pak

P : Mana ada segitiga dan Phitagoras mas? Saya tidak melihat di oret-oretan?

$S_{3}: \quad$ Itu ada di kepala pak heheheheh gampil .....
Ini berarti siswa sudah menginternalisasi hasil pekerjaannya, dia enggan untuk menuliskan secara detail hasil pekerjaannya dikarenakan dia sudah mengerti dan meyakininya. Selanjutnya $\mathrm{S}_{3}$ berpikir jarak dari titik $C$ ke $B H$ adalah $4 \sqrt{3} \mathrm{~cm}$, dikarenakan perpotongan antara diagonal ruang $C E$ dan $B H$ sehingga tinggal membagi dua saja yaitu $4 \sqrt{3} \mathrm{~cm}$. Jika dilihat dari analisi hasil pekerjaan $\mathrm{S}_{3}$, maka $\mathrm{S}_{3}$ termasuk pada jenis antisipasi terinternalisasi.

Berdasarkan hasil analisis dari ketiga subjek di atas diperoleh bahwa siswa pada tingkat analisis berdasarkan teori van Hiele masih belum tepat dalam menyelesaikan soal geometri (kubus). Hal ini memperkuat hasil penelitian-penelitian sebelumnya bahwa pembelajaran geometri masih jauh dari harapan yang diinginkan. Jenis antisipasi yang dilakukan siswa dalam penelitian ini berturut-turut adalah antisipasi analitik, antisipasi kaku, dan antisipasi terinternalisasi. Selanjutnya Lim (2006) mengatakan bahwa siswa dengan jenis antisipasi eksploratif atau antisipasi analitik dapat segera mungkin diperbaiki/diberi bantuan dalam 
pembelajaran di kelas. Artinya guru membutuhkan waktu yang cukup banyak dalam membantu siswa menyelesaikan masalah matematika di kelas jika siswa tidak termasuk dalam antisipasi analitik atau antisipasi eksploratif. Temuan lain dari penelitian ini adalah bahwa pada jenjang kelas yang lebih tinggi belum tentu kemampuan geometri siswa lebih baik. Ini berarti kemampuan geometri/dalam menyelesaikan masalah geometri dibutuhkan pengalaman dalam menyelesaikan suatu masalah dan bukan dipengaruhi faktor usia, meskipun hasil penelitian ini tidak menunjukkan hasil pemahaman geometri siswa yang baik.

\section{Penutup}

Jenis antisipasi yang dilakukan subjek dalam menyelesaikan masalah geometri bangun runag (kubus) berturutturut adalah antisipasi analitik, antisipasi kaku dan antisipasi terinternalisasi. $\mathrm{S}_{1}$ menganalisis masalah yang diberikan dan menetapkan tujuan yang telah direncanakan kemudian menerapkan prosedur penyelesaian masalah. $\mathrm{S}_{1}$ sudah benar dalam memahami masalah kemudian mensketsa bangun geometri yang dimaksud, tetapi hasil akhir yang didapatkan kurang tepat. $\mathrm{S}_{2}$ dapat diklasifikasikan pada jenis antisipasi kaku dimana $S_{2}$ mempertahankan pemahaman yang dimiliki terhadap soal, kemudian $\mathrm{S}_{2}$ tidak memeriksa kembali hasil pekerjaannya. Dia sudah meyakini apa yang diterapkan sudah benar dan tidak perlu diperiksa kembali. $\mathrm{S}_{3}$ dapat diklasifikasikan pada jenis antisipasi terinternalisasi dimana $S_{3}$ secara spontan menerapkan dan menetapkan kriteria masalah.

Jenis antisipasi analitik dan antisipasi eksploratif masih memiliki harapan lebih baik dalam menyelesaikan masalah matematika daripada jenis antisipasi lainnya. Ini sesuai dengan pendapat Lim (2006) bahwa siswa dengan jenis antisipasi analitik masih mampu dikembangkan lagi cara berpikirnya dalam memecahkan masalah matematika sehingga mencapai pemahaman yang "canggih". Hal ini berarti jenis antisipasi analitik memiliki peluang besar mendapatkan pemahaman dan berpikir yang lebih baik.

\section{Pustaka}

Burger, W.F. and Shaughnessy, J.M. 1986b. Characterizing the van Hiele Levels of Development in Geometry. Journal for Research in Mathematics Education, 17(1): 31-48. Reston: NCTM.

Cifarelli, V. V. (1998). The Development of Mental Representations as a Problem Solving Activity. Journal of Mathematic Behavior, 17 (2), 239-264.

Clements, D.H. and Battista, M.T.1992. Geometry and Spatial Reasonning. Dalam Grouws, 
D.A. (Ed.). Handbook of Research on Mathematics Teaching and Learning (hlm. 420-464). New York: MacMillan Publisher Com-pany.

Cobb, P. 1985. Two Children's Anticipation, beliefs, and Motivations. Educational Studies in Mathematics, 16(2), 111-126.

Crowley, M.L. 1987. The van Hiele Model of the Development of Geometric Thought. Dalam Lindqueist, M.M. and Shulte, A.P. (Eds.). Learning and Teaching Geometry K-12 (hlm. 1-16). Reston: NCTM.

D'Augustine, C. and Smith, C.W. 1992. Teaching Elementary School Mathema-tics. Boston: Harpe Collins Publisher Inc.

Fuys, D., Geddes, D., and Tischer, R. 1988. The van Hiele Model of Thingking in Geometry Among Adolescents. Journal for Research in Mathematics Education. Monograph no. 3. Reston: NCTM.

Harel, G. 2006. The DNR System as a Conceptual Framework for Curriculum Development and instruction. In R. Lesh, J. Kaput, E. Hamilton \& J. Zawojewski. Foundations for the future: The Need for New Mathematical Understandings and abilities in the $21^{\text {St }}$ Century. Hillsdale, NJ: Lawrence Erlbaum

Lim, K. (2006). Characterizing students' thinking: Algebraic inequalities and equations. In S. Alatorre, J. L. Cortina, M. Sáiz \& A. Méndez (Eds.), Proc. 28th Annual Meeting of the North American Chapter of the Int. Group for the Psychology of Mathematics Education, (Vol. 2, pp. 102-109). Mérida, México: PME-NA.

Moleong, L. J. 2011. Metodologi Penelitian Kualitatif. Bandung: PT Remaja Rosdakarya.

Putra, Y. dkk. (2005). Pengembangan Media Pembelajaran Matematika Berbantuan Komputer. Laporan karya tulis tidak diterbitkan. Jember: FKIP Universitas Jember.

Sunardi, dkk. 1998. Upaya Peningkatan Kualitas

Pembelajaran Matematika di SLTPN 4 Jember. Laporan penelitian tidak diterbitkan. Lembaga penelitian. Jember: Universitas Jember.

Sunardi, 2000. Tingkat Perkembangan Konsep Geometri Siswa Kelas 3 SLTPN di Jember. (halm.635639). Jember: Prosiding Komperensi Nasional X Matematika.

Sunardi. 2001. Hubungan antara Usia, Tingkat Berpikir dan 
Kemampuan Siswa dalam

Geometri. Dalam prosiding

Seminar Nasional Matematika

"Peran Matematika Memasuki

Milenium III". Jurusan

Matematika FMIPA ITS

Surabaya. Surabaya, 2

Nopember.

Sunardi. 2002. Hubungan antara Tingkat

Penalaran Formal dan Tingkat

Perkembangan Konsep Geometri

Siswa. Jurnal Ilmu Pendidikan,

Vol 9, No. 1.

Usiskin, Z. 1987. Resolving the Continuing Dilemmas in School Geometri Dalam Mary Montgomery L dan Albert P. Shulte (Eds.), Learning and Teaching Geometry, K-12 (halm, 17-31). Amerika: Colombus College dan Oakland Schools.

van de Walle, J.A. 1994. Elementary

School Mathematics. New York:

Longman. van Hiele, P.M. 1999. Developing Geometric Thinking through Activities That Begin with Play. Teaching Children Mathematics, 5(6): 310-316. Reston: NCTM.

Yudianto, E. 2011. Perkembangan Kognitif Siswa Sekolah Dasar di Jember Kota Berdasarkan Teori van Hiele. Prosiding Seminar Nasional Matematika dan Pendidikan Matematika Program Studi Pendidikan Matematika FKIP Universitas Jember, 23 Juli 2011, Halaman 191-200.

Yudianto, E. 2013. Profil Pengetahuan Konseptual dan Pengetahuan Prosedural Siswa dalam Mengidentifikasi Masalah Pecahan. Jurnal AdMathEdu. Universitas Ahmad Dahlan Yogyakarta. Vol.3 No.1. Juni 2013 Halaman 27-36 